\title{
ANALYSIS OF HIGH DOSE AND LONG-TERM PREDNISONE THERAPY ON OSTEOCALCIN LEVELS IN CHILDREN WITH NEPHROTIC SYNDROME (STUDY AT PEDIATRIC DEPARTMENT NEPHROLOGY DIVISION OF DR. SOETOMO TEACHING HOSPITAL SURABAYA)
}

\author{
FEBRINA PRITAYUNI PERMATASARI ${ }^{1}$, NINIK ASMANINGSIH ${ }^{2}$, MARIYATUL QIBTIYAH ${ }^{3}$, YULISTIANI Yulistiani' ${ }^{*}$
}

${ }^{1}$ Master of Clinical Pharmacy, Faculty of Pharmacy, Universitas Airlangga Surabaya, Indonesia. ${ }^{2}$ Department of Pediatric, Division of Nephrology, Dr. Soetomo Teaching Hospital Surabaya, Indonesia. ${ }^{3}$ Department of Pediatric, Pharmacy Installation of Dr. Soetomo Teaching Hospital Surabaya, Indonesia. Email: yulist_r@yahoo.co.id

Received: 16 January 2017, Revised and Accepted: 22 March 2017

ABSTRACT

Objective: The objective of the study to analyze osteocalcin levels in induction and alternate phase, associated with clinical manifestation.

Methods: We conducted a prospective longitudinal study. This study was subject to approval by the Ethics Committee of Dr. Soetomo Teaching Hospital Surabaya. Osteocalcin levels were measured before and after induction phases and 4 weeks after the alternate phase. Samples were collected in the morning at 08.00-09.00 am.

Results: A total of 15 patients were included in this study. The suppression of osteocalcin levels in the induction phase was $53.33 \%$. After the alternate phase, osteocalcin levels increased $175.82 \%$. Clinical manifestation as bone pain/cramps only appeared $33 \%$ in the induction phase and $20 \%$ in the alternate phase. The mean suppression of osteocalcin levels in the group with induction phase duration therapy $\geq 28$ days and without calcium supplementation was higher than 21-27 days and with calcium supplementation. Osteocalcin levels increased in the alternate phase also in patients with and without calcium supplementation. The result of analysis showed there was no significant difference among all groups (p $>0.05)$

Conclusion: Suppression of osteocalcin levels was reversible after the alternate phase. It shows that tapering off regimen is important. Clinical sign as pain bone/cramps almost showed no manifest in all of these patients.

Keywords: Osteocalcin, Nephrotic syndrome, Prednisone, Corticosteroid, High dose prednisone, Long-term prednisone, Bone formation, Bone marker, Pediatric.

(c) 2017 The Authors. Published by Innovare Academic Sciences Pvt Ltd. This is an open access article under the CC BY license (http://creativecommons. org/licenses/by/4. 0/) DOI: http://dx.doi.org/10.22159/ajpcr.2017.v10i6.17124

\section{INTRODUCTION}

Nephrotic syndrome (NS) is a glomerular disease with massive proteinuria $>40 \mathrm{mg} / \mathrm{m}^{2} / \mathrm{h}$ or $>50 \mathrm{mg} / \mathrm{kg} / \mathrm{d}$ or urinary protein creatinine ratio $>2 \mathrm{mg} / \mathrm{mg}$. Other clinical manifestations are hypoalbuminemia $(\leq 2.5 \mathrm{~g} / \mathrm{dl})$ and edema [1-3]. Based on the report, NS incident occurrence of children $<14$ year of age in Indonesia is 6/100.000 [2]. NS patients are treated with high dose and long-term prednisone therapy which may decrease the function of osteoblasts and lead to suppression of bone formation [4,5]. A meta-analysis of over 80 studies in adults found that use of $\geq 5 \mathrm{mg} / \mathrm{d}$ of prednisolone (or equivalent) was associated with significant reductions in bone mineral density (BMD) and an increase in fracture risk within 3-6 months of treatment initiation [6]. Based on systematic review and meta-analysis in children $\leq 18$ years taking longterm systemic glucocorticoid therapy, the prevalence of fracture was $29-45 \%$ [7]. Based on those meta-analysis, NS patients are at risk of losing bone mass which leads to osteopenia, osteoporosis, and fracture. Therefore, bone metabolism in NS patients need to be evaluated.

Biochemical marker such as osteocalcin may be useful in monitoring bone metabolism. Osteocalcin is a noncollagenous protein in mature human bone. It is a small protein of 49 amino acids including three residues of gamma-carboxyglutamic acid and its synthesis is essentially specific to osteoblasts $[8,9]$. Osteocalcin is a sensitive marker to glucocorticoids because it directly affects the expression of osteocalcin at the transcriptional level by binding to the glucocorticoid receptors (GR) and leading to repression of osteocalcin gene up to $40 \%$ of basal levels $[10,11]$. Osteocalcin levels of children with NS in Indonesia have not been established. Besides that, osteocalcin levels after 4 weeks the alternate phase in NS patients have not been evaluated. Therefore, this study is proposed to analyze osteocalcin levels in the induction phase and 4 weeks of the alternate phase which associated with clinical manifestation.

\section{METHODS}

We conducted a prospective longitudinal study from May to October 2016. This study protocol was subject to approval by the Ethics Committee of Dr. Soetomo Teaching Hospital Surabaya. We included children aged $<18$ years who were diagnosed with an initial attack NS, infrequent relapses NS, frequently relapsing NS, and steroid dependent NS. The parents of the patients signed informed consents for this study. The patients with NS steroid resistant were excluded from this study.

NS patients were treated with $60 \mathrm{mg} / \mathrm{m}^{2} / \mathrm{d}$ prednisone or $2 \mathrm{mg} / \mathrm{kg} / \mathrm{d}$ (maximum $60 \mathrm{mg} / \mathrm{d}$ ) for \pm 4 weeks (induction phase), followed by $40 \mathrm{mg} / \mathrm{m}^{2} / \mathrm{d}$ or $1.5 \mathrm{mg} / \mathrm{kg} / \mathrm{d}$ (maximum $40 \mathrm{mg} / \mathrm{d}$ ) on alternate days for \pm 4 weeks (alternate phase). Samples were collected at 08.00-09.00 am from the patients before they started treatment, after the induction phase, and after alternate phase. All patients had normal renal function (glomerular filtration rate $>90 \mathrm{ml} /$ minutes $/ 1.73 \mathrm{~m}^{2}$ ).

Osteocalcin levels were measured accordance with Enzyme-Linked Immunosorbent Assay method. Medical history and clinical data were collected from patient information and based on the medical record.

Nominal data were presented as frequency distribution, and interval data were described as mean and standard deviation. Collected data were analyzed using Statistical Package for the Social Science 20,0. Distribution data were checked with One-Sample Kolmogorov-Smirnov 
Table 1: Baseline characteristics of patients

\begin{tabular}{|c|c|c|}
\hline \multirow[t]{2}{*}{ Patient characteristics } & Total patient $(n=15)$ & Mean \pm SD \\
\hline & \multicolumn{2}{|l|}{ Number of patients $n(\%)$} \\
\hline \multicolumn{3}{|l|}{ Gender } \\
\hline Boys & $9(60)$ & - \\
\hline Girls & $6(40)$ & - \\
\hline \multicolumn{3}{|l|}{ Age (year) } \\
\hline$<2$ & $0(0)$ & - \\
\hline $2-<$ & $4(27)$ & $3.5 \pm 1.3$ \\
\hline $6-<$ & $8(53)$ & $7.5 \pm 1.6$ \\
\hline $12-18$ & $3(20)$ & $14 \pm 1.0$ \\
\hline \multicolumn{3}{|l|}{ Weight (kg) } \\
\hline$\leq 20.9$ & $8(53)$ & $16.4 \pm 3.13$ \\
\hline $21-40.9$ & $5(33)$ & $26.9 \pm 8.05$ \\
\hline $41-60$ & $2(14)$ & $48.5 \pm 2.12$ \\
\hline \multicolumn{3}{|l|}{ Diagnosis } \\
\hline Initial attack nephrotic syndrome & $4(27)$ & - \\
\hline Infrequent relapses nephrotic syndrome & $3(20)$ & - \\
\hline Frequently relapsing nephrotic syndrome & $2(13)$ & - \\
\hline Steroid dependent nephrotic syndrome & $6(40)$ & - \\
\hline \multicolumn{3}{|l|}{ Osteocalcin level before induction $(\mu \mathrm{g} / \mathrm{l})$} \\
\hline$<45$ & $4(27)$ & $19.151 \pm 15.358$ \\
\hline $45-105$ & $4(27)$ & $70.923 \pm 22.976$ \\
\hline$>105$ & $7(46)$ & $134.623 \pm 11.526$ \\
\hline \multicolumn{3}{|c|}{ Cumulative dose of prednisone 1 year before induction (g) } \\
\hline Not taking prednisone & $5(33)$ & - \\
\hline$<5$ & $6(40)$ & $3.1 \pm 1.39$ \\
\hline $5-10$ & $4(37)$ & $5.9 \pm 5.2$ \\
\hline$>10$ & $0(0)$ & - \\
\hline \multicolumn{3}{|c|}{ Duration of prednisone 1 year before induction (days) } \\
\hline Not taking prednisone & $5(33)$ & - \\
\hline $1-225$ & $9(60)$ & $168.2 \pm 53.96$ \\
\hline $226-450$ & $1(7)$ & 229 \\
\hline$>450$ & $0(0)$ & - \\
\hline \multicolumn{3}{|c|}{ Cumulative dose of calcium supplement 1 year before induction (g) } \\
\hline Not taking calcium supplement & $6(40)$ & - \\
\hline$<293$ & $2(13)$ & $175.3 \pm 148.14$ \\
\hline $293-586$ & $7(47)$ & $327.6 \pm 17.29$ \\
\hline \multicolumn{3}{|l|}{ Calcium level before induction } \\
\hline No measurement & $2(13)$ & - \\
\hline Normal $(2.2-2.7 \mathrm{mmol} / \mathrm{l})$ & $13(87)$ & $2.3 \pm 0.13$ \\
\hline Abnormal $(<2.2$ or $>2.7 \mathrm{mmol} / \mathrm{l})$ & $0(0)$ & - \\
\hline \multicolumn{3}{|l|}{ Phosporus level before induction } \\
\hline No measurement & $7(47)$ & - \\
\hline Normal (0.87-2.1 mmol/l) & $8(53)$ & $1.6 \pm 0.21$ \\
\hline Abnormal $(<0.87$ or $>2.1 \mathrm{mmol} / \mathrm{l})$ & $0(0)$ & - \\
\hline \multicolumn{3}{|l|}{ Edema } \\
\hline No edema & $1(7)$ & - \\
\hline Palpebra & $4(26)$ & - \\
\hline Extremitas & $1(7)$ & - \\
\hline Anasarca & $9(60)$ & - \\
\hline \multicolumn{3}{|l|}{ Bone pain/cramps } \\
\hline Yes & $5(33)$ & - \\
\hline No & $10(67)$ & - \\
\hline
\end{tabular}

SD: Standard deviation

test. Differences in osteocalcin levels between phase were checked with Paired t-test and General Linear Model Repeated Measures. Independent t-test and One-Way ANOVA were used to compare differences in osteocalcin levels among groups. For all test, a probability, $\mathrm{p}<0.05$ was examined significant.

\section{RESULTS}

A total of 15 patients ( 9 boys and 6 girls) were enrolled from Pediatric Department Nephrology Division of Dr. Soetomo Teaching Hospital Surabaya. The patients were in the active phase of NS, with either their first attack $(n=4)$ or during a relapse $(n=11)$. Their ages ranged from 2 to 15 years with most of the weight were $\leq 20.9 \mathrm{~kg}$. Before induction phase, $27 \%$ of patient had osteocalcin level in the normal range, $47 \%$ up in the normal range, and $27 \%$ below the normal range. The majority of the patients had normal of calcium and phosphorus levels, also did not experience bone pains/cramps. Table 1 shows baseline characteristics of examined children and history of the duration and cumulative dose of prednisone for 1 year before induction $(t=0)$.

Osteocalcin levels of patients before treatment started $(t=0)$, after induction phase $(\mathrm{t}=1)$, and after alternate phase $(\mathrm{t}=2)$ were shown in Table 2. Almost all patients had osteocalcin levels at $\mathrm{t}=0$ higher than the normal range, except four patients (AM, KY, AP, and RA) whose osteocalcin levels were lower than normal range. Other than KY, osteocalcin levels at $\mathrm{t}=2$ were higher than the normal range. Three patients (MA infrequent relapses NS, AP frequently relapsing NS, RAdependent steroid NS) had osteocalcin profile different from other patients, which osteocalcin levels at $\mathrm{t}=0$ lower than $\mathrm{t}=1$. Osteocalcin suppression of DA in the induction phase was as low as $2.44 \%$ compared 
Table 2: Osteocalcin levels of patients

\begin{tabular}{|c|c|c|c|c|}
\hline \multirow[t]{2}{*}{ Patients code } & \multicolumn{4}{|c|}{ Osteocalcin levels $(\mu \mathrm{g} / \mathrm{l})$} \\
\hline & Normal range & $\mathbf{t}=\mathbf{0}$ & $\mathbf{t}=\mathbf{1}$ & $\mathbf{t}=\mathbf{2}$ \\
\hline \multicolumn{5}{|c|}{ Initial attack nephrotic syndrome } \\
\hline $\mathrm{AM}$ & $44-93$ & 37.892 & 16.931 & 63.635 \\
\hline \multicolumn{5}{|l|}{$(\mathrm{G} / 3 \mathrm{y} / 11.8 \mathrm{~kg})$} \\
\hline DI & $50-89$ & 137.321 & 34.434 & 141.462 \\
\hline \multicolumn{5}{|l|}{ (G/8 y/20 kg) } \\
\hline KY & $64-70$ & 24.274 & 2.458 & 34.818 \\
\hline \multicolumn{5}{|l|}{$(\mathrm{B} / 2 \mathrm{y} / 12.3 \mathrm{~kg})$} \\
\hline AI & $66-102$ & 146.713 & 30.976 & 180.370 \\
\hline \multicolumn{5}{|l|}{ (B/14 y/47 kg) } \\
\hline Mean \pm SD & & $86.550 \pm 64.403^{1 *}$ & $21.200 \pm 14.608^{2 *}$ & $105.071 \pm 67.445^{3 *}$ \\
\hline$(\%)$ & & - & $\downarrow 75.51 \%$ & $\uparrow 395.62 \%$ \\
\hline \multicolumn{5}{|c|}{ Infrequent relapses nephrotic syndrome } \\
\hline JA & $53-97$ & 138.218 & 39.088 & 124.855 \\
\hline \multicolumn{5}{|l|}{ (G/7 y/18 kg) } \\
\hline SR & $53-97$ & 128.356 & 10.740 & 63.806 \\
\hline \multicolumn{5}{|l|}{$(\mathrm{G} / 7 \mathrm{y} / 21.8 \mathrm{~kg})$} \\
\hline MA & 49-104 & 49.411 & 118.174 & 145.386 \\
\hline \multicolumn{5}{|l|}{$(\mathrm{B} / 7 \mathrm{y} / 20.2 \mathrm{~kg})$} \\
\hline Mean \pm SD & & $105.328 \pm 48.676^{1 *}$ & $56.001 \pm 55.678^{2 *}$ & $111.349 \pm 42.434^{3 *}$ \\
\hline$\%$ & & - & $\downarrow 46.83 \%$ & $\uparrow 98.83 \%$ \\
\hline \multicolumn{5}{|c|}{$\begin{array}{l}\text { Frequently relapsing nephrotic } \\
\text { syndrome }\end{array}$} \\
\hline AR & $51-84$ & 114.762 & 51.700 & 141.023 \\
\hline \multicolumn{5}{|l|}{$(\mathrm{B} / 6 \mathrm{y} / 16.1 \mathrm{~kg})$} \\
\hline $\mathrm{AP}$ & $56-80$ & 2.458 & 7.667 & 46.174 \\
\hline \multicolumn{5}{|l|}{ (B/11 y/50 kg) } \\
\hline Mean \pm SD & & $58.610 \pm 79.411^{1 *}$ & $29.684 \pm 31.136^{2 *}$ & $93.599 \pm 67.068^{3 *}$ \\
\hline$\%$ & & - & $\downarrow 49.35 \%$ & $\uparrow 215.32 \%$ \\
\hline \multicolumn{5}{|c|}{ Steroid dependent nephrotic syndrome } \\
\hline $\mathrm{RF}$ & 61-105 & 103.339 & 32.342 & 132.283 \\
\hline \multicolumn{5}{|l|}{ (B/15 y/29.7 kg) } \\
\hline ND & $53-90$ & 63.166 & 40.753 & 128.825 \\
\hline \multicolumn{5}{|l|}{$(\mathrm{B} / 4 \mathrm{y} / 16 \mathrm{~kg})$} \\
\hline RA & $51-84$ & 11.978 & 21.029 & 56.164 \\
\hline \multicolumn{5}{|l|}{ (B/6 y/17 kg) } \\
\hline DA & $66-88$ & 129.361 & 126.208 & 142.190 \\
\hline \multicolumn{5}{|l|}{$(\mathrm{G} / 5 \mathrm{y} / 21 \mathrm{~kg})$} \\
\hline $\mathrm{NH}$ & $50-89$ & 67.776 & 45.235 & 136.766 \\
\hline \multicolumn{5}{|l|}{ (G/8 y/22 kg) } \\
\hline $\mathrm{FH}$ & $74-98$ & 147.632 & 30.233 & 139.123 \\
\hline \multicolumn{5}{|l|}{ (B/13 y/39.8 kg) } \\
\hline Mean \pm SD & & $87.209 \pm 49.605^{1 *}$ & $49.300 \pm 38.613^{2 *}$ & $122.559 \pm 32.875^{3 *}$ \\
\hline$\%$ & & - & $\downarrow 43.47 \%$ & $\uparrow 148.60 \%$ \\
\hline Mean \pm SD (15 patients) & & $86.844 \pm 52.380^{4 *}$ & $40.531 \pm 36.030^{4 * 5 *}$ & $111.792 \pm 45.268^{5 *}$ \\
\hline$\%$ & & - & $\downarrow 53.33$ & $\uparrow 175.82$ \\
\hline Range & & $2.458-147.632$ & $2.458-126.208$ & $34.818-180.370$ \\
\hline
\end{tabular}

${ }^{1 *} \mathrm{p}=0.847,{ }^{2 *} \mathrm{p}=0.572,{ }^{3 *} \mathrm{p}=0.889,{ }^{4 *} \mathrm{p}=0.007(\mathrm{t}=0$ vs. $\mathrm{t}=1),{ }^{5 *} \mathrm{p}=0.000$ ( $\mathrm{t}=1$ vs. $\left.\mathrm{t}=2\right)$, G: Girl, B: Boy, SD: Standard deviation, $\mathrm{y}:$ Years

to high percentage of other patients. There was no significant difference in osteocalcin level of initial attack, infrequent relapses, frequently relapsing, and dependent steroid NS at $\mathrm{t}=0, \mathrm{t}=1, \mathrm{t}=2(\mathrm{p}=0.847 ; \mathrm{p}=0.572$; $\mathrm{p}=0.889$, respectively).

The mean osteocalcin level of 15 patients was presented in Table 2 showed that after the induction phase, osteocalcin levels decrease $53.33 \%(86.844 \pm 52.380$ to $40.531 \pm 36.030 \mu \mathrm{g} / \mathrm{l})$ and after alternate phase increase $175.82 \%$ ( $40.531 \pm 36.030$ to $111.792 \pm 45.268 \mu \mathrm{g} / \mathrm{l})$. There was a significant difference between osteocalcin levels after induction phase versus (vs.) before treatment and after alternate phase versus induction phase ( $\mathrm{p}=0.007$ and $\mathrm{p}=0.000$, respectively).

Data in Table 3 that showed the mean suppression of osteocalcin levels in group with induction phase duration therapy $\geq 28$ days and without calcium supplementation was higher than 21-27 days and with calcium supplementation $(-56.752 \pm 58.674$ and $-64.467 \pm 67.921$ vs. $-25.434 \pm 51.932$ and $-30.376 \pm 43.166) \mu \mathrm{g} / \mathrm{l}$, respectively. Osteocalcin levels increased in the alternate phase also in patients with and without calcium supplementation. The result of analysis showed that there was no significant difference among all groups ( $\mathrm{p}>0.05$ ).

Clinical manifestation as bone pain/cramps only appeared 33\% in the induction phase and $20 \%$ in the alternate phase showed in Table 4.

\section{DISCUSSION}

Osteocalcin levels of 7 out of 15 patients at $\mathrm{t}=0$ was higher than the normal range. As shown in Table 2 indicate that children in growth period associated with increased activity of osteoblast [8]. Normal range is osteocalcin levels in Caucasian children. The difference of these ethnic may be caused difference of BMD. Based on the report, the prevalence of vitamin D deficiency in people who live in high-latitude regions, such as Caucasian children was higher than people in tropical regions like Indonesian children [12]. Deficiency of vitamin D will be 
Table 3: Osteocalcin change based on duration therapy and consume of calcium supplementation

\begin{tabular}{llll}
\hline Group & Number of patients & Mean \pm SD of osteocalcin change $(\boldsymbol{\mu g} / \mathbf{l})$ & Significancy $(\mathbf{p})$ \\
\hline Induction phase $21-27$ days & 5 & $-25.434 \pm 51.932$ & 0.332 \\
Induction phase $\geq 28$ days & 10 & $-56.752 \pm 58.674$ & 0.325 \\
Alternate phase $\leq 14$ days & 6 & $83.682 \pm 23.654$ & \\
Alternate phase 14 days & 9 & $62.980 \pm 45.191$ & 0.261 \\
With calcium supplement (induction phase) & 8 & $-30.376 \pm 43.166$ & \\
Without calcium supplement (induction phase) & 7 & $-64.467 \pm 67.921$ & 0.067 \\
With calcium supplement (alternate phase) & 10 & $58.547 \pm 30.793$ & \\
Without calcium supplement (alternate phase) & 5 & $96.688 \pm 42.694$ & \\
\hline
\end{tabular}

SD: Standard deviation

Table 4: Clinical manifestation

\begin{tabular}{|c|c|c|c|}
\hline \multirow[t]{2}{*}{ Patient code } & \multicolumn{3}{|c|}{ Bone pain/cramp } \\
\hline & $t=0$ & $t=1$ & $t=2$ \\
\hline \multicolumn{4}{|c|}{$\begin{array}{l}\text { Initial attack nephrotic } \\
\text { syndrome }\end{array}$} \\
\hline $\mathrm{AM}$ & No & No & No \\
\hline DI & No & No & No \\
\hline KY & No & No & No \\
\hline $\mathrm{AI}$ & No & Yes & No \\
\hline \multicolumn{4}{|c|}{$\begin{array}{l}\text { Infrequent relapses } \\
\text { nephrotic syndrome }\end{array}$} \\
\hline JA & Yes & No & Yes \\
\hline SR & No & No & No \\
\hline MA & Yes & Yes & No \\
\hline \multicolumn{4}{|c|}{$\begin{array}{l}\text { Frequently relapsing } \\
\text { nephrotic syndrome }\end{array}$} \\
\hline AR & No & Yes & No \\
\hline $\mathrm{AP}$ & Yes & No & No \\
\hline \multicolumn{4}{|c|}{$\begin{array}{l}\text { Steroid dependen } \\
\text { nephrotic syndrome }\end{array}$} \\
\hline $\mathrm{RF}$ & No & No & No \\
\hline ND & No & Yes & No \\
\hline RA & Yes & No & Yes \\
\hline DA & Yes & No & No \\
\hline $\mathrm{NH}$ & No & No & No \\
\hline $\mathrm{FH}$ & No & Yes & Yes \\
\hline \multirow[t]{2}{*}{ Total (\%) } & Yes=5 (33) & Yes=5 (33) & Yes=3 (20) \\
\hline & $\mathrm{No}=10(67)$ & $\mathrm{No}=10(67)$ & $\mathrm{No}=12(80)$ \\
\hline
\end{tabular}

reduced transcription of osteocalcin; therefore, osteocalcin level in most patients was higher than normal range [13]. Difference of ethnic also might cause genetic variation, polymorphisms in the promoter gene of osteocalcin (rs1800247), vitamin D receptor gene, and regulatory region of the type 1 collagen gene, COLIA1, also mutation of low-density lipoprotein receptor-related protein 5 (LRP5) therefore may cause difference osteocalcin levels [14-16]. Four patients (AM, KY, $\mathrm{AP}$, and RA) whose osteocalcin levels lower than normal range may be caused by low quality of BMD in these patients.

Three patients (MA infrequent relapses NS, AP frequently relapsing NS, RA-dependent steroid NS) had osteocalcin profile different from other patients, whose osteocalcin levels at $t=0$ was lower than $t=1$ which caused by a history of high-dose and long-term prednisone since 2015, 2013 , and 2011, respectively. The suppression osteocalcin of DA in the induction phase as low as $2.44 \%$ because this patient had high protein intake. Protein intake affects bone in several ways, such as providing the structural matrix of bone, optimizing insulin-like growth factor-1 levels, and reported increasing intestinal calcium absorption [17].

Osteocalcin levels of initial attack, infrequent relapses, frequently relapsing, and dependent steroid $\mathrm{NS}$ at $\mathrm{t}=0, \mathrm{t}=1, \mathrm{t}=2$ were not significantly different because patients were given the same dose. Kano et al. [18] reported osteocalcin levels of children with steroidresponsive NS 4 weeks after starting prednisolone therapy (induction phase) decreased $68.54 \%$. The other study that was reported by
Mohamed and Abdul-Latif [19], osteocalcin levels decreased 30.59\% after 1 month of therapy in the initial attack NS. The decreasing of osteocalcin levels after induction phase also occurred in 15 patients in this study. Osteocalcin levels of 15 patients decrease $53.33 \%$ $(86.844 \pm 52.380-40.531 \pm 36.030 \mu \mathrm{g} / \mathrm{l})$. It showed a decreasing function of osteoblast which leads to osteopenia, osteoporosis, and increasing risk of fracture. This suppression was caused by prednisone induce nuclear factors of the CCAAT enhancer binding protein family and the induction of peroxisome proliferator-activated receptor $\gamma 2$, both of which play essential roles in adipogenesis. An additional mechanism by which prednisone inhibit osteoblast cell differentiation is by opposing $\mathrm{Wnt} / \beta$ catenin signaling. Prednisone has pro-apoptotic effects on osteoblasts and osteocytes due to activation of caspase 3, a common downstream effector of several apoptotic signaling pathways [4,5]. Besides that, prednisone has directly affected the expression of osteocalcin at the transcriptional level by binding to the GR and subsequently to specific recognition sequences in the proximal promoter leading to a repression of osteocalcin gene [10].

Kano et al. [18] observed osteocalcin levels 8 weeks after the alternate phase and showed increasing from $6.7 \pm 2.6 \mu \mathrm{g} / \mathrm{l}$ to $15.0 \pm 6.4 \mu \mathrm{g} / \mathrm{l}$. As mentioned previously that study of osteocalcin levels after 4 weeks the alternate phase in NS patients have not been evaluated. Therefore, our study evaluated it and the result showed increasing $175.82 \%$ $(40.531 \pm 36.030-111.792 \pm 45.268 \mu \mathrm{g} / \mathrm{l})$. This increasing indicates that the suppression of osteocalcin is reversible while tapering dose of prednisone.

The mean suppression of osteocalcin levels in the group with induction phase duration therapy $\geq 28$ days was higher than 21-27 days. This condition as reported Godschalk and Downs [20] and Biyikli et al. [21] that the suppression of osteocalcin is dose dependent, which the higher dose of prednisone, the higher suppression of osteocalcin levels. Patients without calcium supplement had osteocalcin levels more suppressed than with calcium supplement. This result shows that patients without calcium supplement are at risk of hypocalcemia, thus stimulates parathyroid hormone (PTH). PTH acts on osteoclast by increasing receptor activator of $\mathrm{NF}-\kappa \mathrm{B}$ ligand release, leading to promotion of osteoclastogenesis and reduce osteoblastogenesis, therefore suppress transcription of osteocalcin [22]. It shows that calcium supplement should be given to prevent hypocalcemia in NS patient.

Variation on increasing of osteocalcin levels in the alternate phase is affected by BMD each patient and intake patients. Dietary such as milk, fish, egg, and green leaves (spinach, broccoli) is intake high calcium, protein, vitamin $\mathrm{D}$, and vitamin $\mathrm{K}$ which may increase transcription of osteocalcin $[23,24]$.

\section{CONCLUSION}

Suppression of osteocalcin levels was reversible after alternate phase. It shows that tapering off regimen is important. Clinical sign as pain bone/cramps almost showed no manifest in all of these patients.

\section{ACKNOWLEDGMENT}

This study was supported by scholarship program from the Ministry of Health Republic of Indonesia. We would like to thank the following 
individuals who contributed to the study likely the children and their families who participated in the study, making this research possible; Muhammad Riza Kurniawan, Dr. SpA and all members of Dr. Soetomo Teaching Hospital Surabaya for their assistance in collecting data for this study; all staff of the Magister of Clinical Pharmacy, Airlangga University, Surabaya.

\section{REFERENCES}

1. KDIGO. KDIGO clinical practice guideline for glomerulonephritis. Kidney Int Suppl KDIGO 2012;2 Suppl 2:143-274.

2. Trihono PP, Alatas H, Tambunan T, Pardede SO. Konsensus Tata Laksana Sindrom Nefrotik Idiopatik Pada Anak. Edisi kedua. Jakarta: Badan Penerbit Ikatan Dokter Anak Indonesia; 2012. p. 1-20.

3. Andolino TP, Reid-Adam J. Nephrotic syndrome. Pediatr Rev 2015;36(3):117-25.

4. Canalis E, Mazziotti G, Giustina A, Bilezikian JP. Glucocorticoidinduced osteoporosis: Pathophysiology and therapy. Osteoporos Int 2007;18(10):1319-28.

5. Tripathy A, Adiga S, Shah HH, Shanbhag TV, Kumar DM. Retrospective study of clinical profile and drug prescribing pattern in osteoporosis in a tertiary care hospital. Int J Pharm Pharm Sci 2015;7(10):390-3.

6. Liu D, Ahmet A, Ward L, Krishnamoorthy P, Mandelcorn ED, Leigh R, et al. A practical guide to the monitoring and management of the complications of systemic corticosteroid therapy. Allergy Asthma Clin Immunol 2013;9(1):30

7. Hansen KE, Kleker B, Safdar N, Bartels CM. A systematic review and meta-analysis of glucocorticoid-induced osteoporosis in children. Semin Arthritis Rheum 2014;44(1):47-54.

8. Jagtap VR, Ganu JV. Serum osteocalcin: A specific marker for bone formation in postmenopausal osteoporosis. Int $\mathrm{J}$ Pharm Biol Sci 2011;1(4):510-7.

9. Ali SH, Kasim AA. Relationship between undercarboxylated osteocalcin and osteoprotegerin in knee osteoarthritis. Int J Pharm Pharm Sci 2014;6(11):344-6.

10. Ivaska K. Osteocalcin. Novel insights into the use of osteocalcin as a determinant of bone metabolism. Finland: Institute of Biomedicine,
Department of Anatomy, University of Turku; 2005. p. 1-114.

11. Lee AJ, Hodges S, Eastell R. Measurement of osteocalcin. Ann Clin Biochem 2000;37:432-46.

12. Correia A, Azevedo Mdo S, Gondim F, Bandeira F. Ethnic aspects of vitamin D deficiency. Arq Bras Endocrinol Metabol 2014;58(5):540-4.

13. Neve A, Corrado A, Cantatore FP. Osteocalcin: Skeletal and extraskeletal effects. J Cell Physiol 2013;228(6):1149-53.

14. Mitchell BD, Cole SA, Bauer RL, Iturria SJ, Rodriguez EA, Blangero J, et al. Genes influencing variation in serum osteocalcin concentrations are linked to markers on chromosomes 16q and 20q. J Clin Endocrinol Metab 2000;85(4):1362-6

15. Davies JH, Evans BA, Gregory JW. Bone mass acquisition in healthy children. Arch Dis Child 2005;90(4):373-8.

16. McGuigan F, Kumar J, Ivaska KK, Obrant KJ, Gerdhem P, Akesson K. Osteocalcin gene polymorphisms influence concentration of seum osteocalcin and enhance fracture identification. J Bone Miner Res 2010;25(6):1392-9.

17. Heaney RP, Layman DK. Amount and type of protein influences bone health. Am J Clin Nutr 2008;87(5):1567S-70.

18. Kano K, Hoshi M, Nishikura K, Yamada Y, Arisaka O. Skeletal effects of short-term prednisolone therapy in children with steroid-responsive nephrotic syndrome. Clin Exp Nephrol 2001;5:40-3.

19. Mohamed GB, Abdel-Latif EA. Serum osteoprotegerin (OPG) in children with primary nephrotic syndrome. Saudi J Kidney Dis Transpl 2011;22(5):955-62.

20. Godschalk MF, Downs RW. Effect of short-term glucocorticoids on serum osteocalcin in healthy young men. J Bone Miner Res 1988;3(1):113-5

21. Biyikli NK, Emre S, Sirin A, Bilge I. Biochemical bone markers in nephrotic children. Pediatr Nephrol 2004;19(8):869-73.

22. Freundlich M, Alonzo E, Bellorin-Font E, Weisinger JR. Increased osteoblastic activity and expression of receptor activator of NFkappaB ligand in nonuremic nephrotic syndrome. J Am Soc Nephrol 2005;16(7):2198-204

23. Lee WT, Jiang J. Calcium requirements for Asian children and adolescents. Asia Pac J Clin Nutr 2008;17 Suppl 1:33-6.

24. Pankova S, Tsvetkova D. Role of phytoestrogens in prevention of osteoporosis. Int J Curr Pharm Res 2015;7(2):1-6. 